Acta vet. scand. $1968,9,71-85$.

From the Research Station of the Veterinary Institute, Skara, Sweden.

\title{
A METHOD FOR GAS CHROMATOGRAPHIC DETERMINATION OF 11 AMINO ACIDS IN PROTEIN HYDROLYSATE*)
}

\author{
By \\ Gunnar Carlström
}

The analytical determination of amino acids has been one of the great problems of chemistry ever since the discovery of the nature of the proteins; the problem has thus existed for more than a century. Previously it was necessary to take the long, circumstantial and uncertain course of performing as many analyses on each sample as there were amino acids in the sample. Only during the last decades simpler and quicker methods have been developed, all of which are based on some form of chromatographic separation.

This latter phase in the development was initiated by the introduction of partition chromatography by Martin \& Synge (1941 a, b) and by its variant, paper chromatography, by Consden et al. 1944. These two procedures, which have since come into use in so many other fields, were originally devised precisely for the analysis of amino acids. Since then considerable work has been done on paper chromatography of amino acids, and in some cases it has even proved advantageous to convert the amino acids into coloured or fluorescent derivatives before chromatography, e. g. to the yellow dinitrophenyl (DNP) amino acids (Biserte et al. 1959).

*) This study was made possible by a grant from "Jordbrukets forskningsråd". 
Thin-layer chromatography, of amino acids as well as their derivatives, yields roughly the same result as paper chromatography, though usually much more quickly and with greater precision (Brenner et al. 1962).

Other methods that have not yet been used so much are high voltage electrophoresis on thin layers (Katz \& Lewis 1966) and chromatography on polyamide layers (Wang et al. 1966). All the methods mentioned hitherto, with the exception of partition chromatography are well suited for analysis of large series of samples, but they have the disadvantage of not, or only in occasional instances, being quantitative.

The problem of quantitative analysis of all amino acids in protein hydrolysate in not too complicated a way was finally solved by Moore \& Stein $(1949,1951,1954 \mathrm{a}, \mathrm{b})$. The method consists of column chromatography on ion-exchange resins. The technique has since been made automatic, so that a minimum of manual work is needed for the analysis. Despite this it has certain serious disadvantages. It is slow and is not at all suited for serial analyses. It also requires expensive apparatus which cannot be used for other analyses. It is therefore hardly usable except in special laboratories.

What is lacking at present is a fairly quick quantitative method which, without major rearrangement of apparatus, can be performed with the ordinary resources of a modern laboratory and which is adapted for serial analyses for which column chromatography is unsuited.

At first sight gas chromatography appears ideal for such a purpose. But certain difficulties are involved in gas chromatography precisely of amino acids. Being non-volatile, it is inconceivable that an unmodified amino acid should be determined by gas chromatography. In pyrolysis gas chromatography the sample is pyrolysed in an auxiliary unit connected to the gas chromatograph, and the pyrolysis products enter directly into the column and produce a characteristic pattern. Several authors (Winter \& Albro 1964, Stack 1965, Kanomata \& Mashiko 1966) report good results, but the method is still very undeveloped.

It is, therefore, necessary to transform the amino acids into volatile products. This can be done in two ways, either through a change of the internal structure of the amino acid or by reactions such as esterification and acylation which inactivate the carboxyl or amino group or both. 
Several experiments based on the first type of method have been reported. In the well-known ninhydrin reaction aldehydes are formed under loss of both carboxyl and amino groups, as studied by Virtanen \& Rautanen (1945-46, 1947). On the basis of their results gas chromatography of the aldehydes has been studied by Bier \& Teitelbaum (1959) and by Zlatkis et al. (1960); the latter also arranged for the reaction to take place in an auxiliary apparatus in order to be able to inject the amino acid mixture directly and obtain a chromatogram of the aldehydes. The method is limited, however, to the relatively few amino acids which yield volatile aldehydes. Bier \& Teitelbaum also tried to decarboxylate the amino acids to form amines, but the yields were poor even though most of the amino acids reacted as expected.

A method intermediate between the two types was proposed by Liberti (1958), namely, by means of van Slyke's nitrite reaction, to convert the amino acids into hydroxy acids, methylate the hydroxy acids and gas-chromatograph the esters. I have made a thorough study of the method and came to the conclusion that a further breakdown of the hydroxy acids is inevitable. The results are far from quantitative, therefore, even though the reactions are surprisingly well reproducible. The decomposition products, moreover, cause very serious disturbances on the gas chromatograms. Similar conclusions are reported by Wagner \& Rausch (1963) in their studies of the yield of hydroxy acids in the same reaction.

The most common type of method for obtaining volatile amino acid derivatives is that in which the internal structure of the amino acids is left intact while groups are added which make the derivative volatile. The simplest conceivable method of this type - formation of methyl esters of the amino acids - was tried by Bayer et al. (1957), but many of the methyl esters as well appear to be too difficult to volatilize for gas chromatography. In general one may say that both the amino group and the carboxyl group must be bound if the resulting compound is to be sufficiently volatile. An important exception to this rule, however, was revealed by the studies of Rühlmann \& Michael (1965). They worked with trimethyl silyl compounds and, though both the amino group and the carboxyl group can well be trimethylsilylated, these authors found that gas chromatography is best done with the trimethyl silyl esters (thus with the amino 
groups free). Both groups have been bound in works by Losse et al. (1962) ( $\mathrm{N}$-formyl amino acid methyl esters), Johnson et al. (1961) (N-acetyl amino acid methyl esters) and Youngs (1959) (N-acetyl amino acid butyl esters). The methyl esters of the DNP amino acids have been gas-chromatographed by Ishii \& Witkop $(1963,1964)$ and by Ikekawa et al. (1966).

The most used, and apparently most promising, methods are those based on N-trifluoroacetyl (TFA)-amino acid esters. Fairly simple procedures give a practically $100 \%$ yield of most esters, and many of the esters are well suited to gas chromatography. Which ester to use is a moot question. Lower esters, like methyl esters, are more volatile, and the chance of being able to determine amino acids with high molecular weight is greater, but on the other hand it is more difficult to separate the amino acids on the chromatograms. The reverse applies to the higher esters, such as amyl esters. The methyl esters were used, for example, by Saroff \& Karmen (1960), Wagner \& Winkler (1961) and $H a-$ gen \& Black (1965), the butyl esters by Zomzely et al. (1962), Lamkin \& Gehrke (1965), Gehrke et al. (1965) and Gehrke \& Shahrokhi (1966). Darbre \& Blau (1965) and Blau \& Darbre $(1965,1967)$, describe the synthesis of all esters, from methyl to amyl, but they themselves prefer to work with the amyl esters. In the present study the butyl esters were used, being synthetized by a modification of the method of Lamkin \& Gehrke.

Most studies of gas chromatography of amino acids published hitherto have been of a theoretical nature; very few applications have been reported. Ishii \& Witkop (1963, 1964) gas-chromatographed the DNP amino acid methyl esters from hydrolysates of Gramicidin A and "seco-Gramicidin A", but used the method only for detection of the amino acids. Ikekawa et al. used the same derivatives of free amino acids in serum, and their method is quantitative. The only chromatograms of protein hydrolysate in the available literature are those published by Gehrke \& Shahrokhi, two chromatograms of TFA amino acid butyl esters, one from casein hydrolysate and the other from hydrolysate of bovine serum albumin. In an earlier study Gehrke et al. showed that quantitative gas chromatography of these amino acid derivatives is possible, but they did not employ it for the abovementioned chromatograms. 


\section{METHOD}

Hydrolysis. (This method has been employed on serum and serum proteins). A quantity of protein solution corresponding to about $5 \mathrm{mg}$ protein (the volume should not exceed $0.1 \mathrm{ml}$ ) and $0.5 \mathrm{ml} 2.5 \mathrm{~N}$ hydrochloric acid is pipetted into a $2 \mathrm{ml}$ ampoule. The ampoule is sealed and left standing at a temperature of about $120^{\circ} \mathrm{C}$ for $48 \mathrm{hrs}$. After it has cooled down, it is opened and the contents are transferred to a centrifugal tube. The ampoule is rinsed with $0.5 \mathrm{ml}$ of water, which is added to the sample in the centrifugal tube. After centrifugation the liquid is carefully poured into a glass stoppered test tube. The centrifugal tube is rinsed with $0.5 \mathrm{ml}$ water, which is centrifuged and then transferred to the test tube. The contents of the test tube are evaporated to dryness in Rotavapor at reduced pressure and $60^{\circ} \mathrm{C}$.

A standard solution is made, consisting of equal parts by weight of the following amino acids: Ala, Asp, Glu, Ile, Leu, Lys, Met, Phe, Pro, $\left.\mathrm{Val}^{\star}\right)$. For each series of hydrolyses a volume of this standard solution containing $5 \mathrm{mg}$ amino acid mixture is pipetted into each of two ampoules. These standards are "hydrolysed" and treated in the sequel exactly in the same way as the samples.

$N$-TFA amino acid butyl esters. Into each of the test tubes with evaporated hydrolysate and standards, respectively, is pipetted $1 \mathrm{ml}$ of $1.2 \mathrm{~N}$ butanolic hydrochloric acid (made by blowing dry $\mathrm{HCl}$ gas into n-butanol). Glass stoppers are inserted and the tubes are shaken at $90^{\circ} \mathrm{C}$ for $3 \mathrm{hrs}$. The samples are then evaporated to dryness in Rotavapor under reduced pressure at $60^{\circ} \mathrm{C}$. After cooling of the tubes $0.1 \mathrm{ml}$ of trifluoroacetic anhydride is added. Stoppers are inserted and the tubes are left to stand overnight. $0.5 \mathrm{ml}$ of chloroform is then added and is poured off into a new stoppered test tube, making sure that no precipitate follows with it. The first tube is washed with $0.5 \mathrm{ml}$ of chloroform, which is transferred to the other tube. The chloroform is now evaporated in Rotavapor at reduced pressure and room temperature. The remainder is dissolved in $0.1 \mathrm{ml}$ of ethyl methyl ketone. The sample is now ready for gas chromatography.

Gas chromatography. A Perkin-Elmer gas chromatograph $\mathbf{8 8 0}$

*) The abbreviations for amino acids used here and in the sequel follow the 1965 recommendations of IUPAC-IUB. 
with double column system and flame ionization detector was used. Columns: $2 \mathrm{~m}$ steel columns, $1 / \mathrm{s}^{\prime \prime}$ dia., with $1 \%$ Carbowax 1500 on Chromosorb W, 80-100 mesh, acid-washed, DMCStreated. Carrier gas: helium, $30 \mathrm{ml} /$ column $/ \mathrm{min}$. Temperature of injector block: $350^{\circ} \mathrm{C}$. Temperature programming: $8^{\circ} \mathrm{C} / \mathrm{min}$. from $100^{\circ} \mathrm{C}$ to $235^{\circ} \mathrm{C}$. One of the two standards belonging to a series is chromatographed before and the other after the series. If an entire series cannot be chromatographed at one time, each cycle of analyses starts with one standard and ends with the other.

Calculations. All amino acid peaks are planimetered and their areas are expressed in arbitrary planimetric units. For each amino acid the areas are added from the two standards. The total weight of an amino acid in the two standards injected is taken arbitrarily as 1 unit. This quantity is the same for all amino acids. The ratio of the area of an amino acid in one sample to the total area of the amino acid in the two standards is then equal to the weight of the amino acid in the sample expressed in the arbitrary weight unit. The weights of all amino acids in the sample are added, and the result of the analysis is expressed as the percentage of each amino acid in relation to the total quantity of amino acids determined in that sample. The possibility of determining the percentage of an amino acid in relation to the weight of the sample is discussed below.

\section{RESULTS AND DISCUSSION}

As is evident from the survey of the literature, the best prospects of finding a quantitative method of analysing amino acids in a very large number of samples should lie in gas chromatography. Very little, however, has been done to put gas chromatography of amino acids to practical use, and the present study must be viewed as one of the first steps in this direction rather than as an account of a perfected method.

The TFA amino acid esters appear to offer the best prospects of a good result. The main aim should be a maximum of simplicity. The best methods of making amino acid derivatives have been so thoroughly elaborated by the two research teams, Darbre $\&$ Blau and Gehrke et al., that there is very little to be gained in the way of simplification in that sphere. The simplification must therefore lie in the choice of type of column. Two factors have been taken into account in this respect. In the first place a single 
column must be able to separate all the amino acid derivatives that can be determined. More than one chromatogram per sample would make the method too slow. In the second place the column should be readily reproducible, as a very large number of analyses would use up several columns. The choice fell on the column described under Method, which has a single stationary phase and fairly well separates the low molecular acids as well as the difficult triplet methionine, aspartic acid and phenylalanine. But it proves that only 11 of the 19 amino acids which frequently occur in proteins can be determined with assurance. Those inaccessible to analysis are Arg, Cys, Hyp, His, Ser, Thr, Trp and Tyr. Darbre \& Blau (1966) relate that gas chromatography on certain polar stationary phases breaks down the TFA esters of hydroxy amino acids and of cysteine. No less than five of the missing acids belong to this group, namely Cys, Hyp, Ser, Thr and Tyr. The instability of these esters is also clearly apparent from Figs. 1 and 2. Fig. 1 shows two chromatograms of an amino acid mixture containing also hydroxy amino acids. Here there are several large unidentified peaks which presumably derive from these acids. Fig. 2 shows three chromatograms of protein hydrolysate. Here the unidentified peaks are small, although thinlayer chromatography of these particular samples revealed the presence of fairly large quantities of serine as well as of threonine. The instability is seen even more clearly in the unpublished chromatograms of corresponding standard samples. Here, again, the unidentified peaks are small although the amino acid mixture is the same as in Fig. 1.

Arginine can be trifluoroacetylated only under special circumstances according to Gehrke et al. (1965), and histidine and tryptophane show doubtful peaks even on the best chromatograms in the literature.

Now that the possibilities and limitations of the method had been recognized, it was used for investigating which hydrolysis procedure produced the best result for serum proteins. (In all cases hydrolysis was done in ampoules at about $120^{\circ} \mathrm{C}$ ). It was found that isoleucine disappeared in alkaline hydrolysis with barium hydroxide, so that the method must be considered unsuitable. An acid hydrolysis method should therefore be used, and hydrolysis with hydrochloric acid was investigated. It was found that if the hydrolysis time was extended to as long as 48 


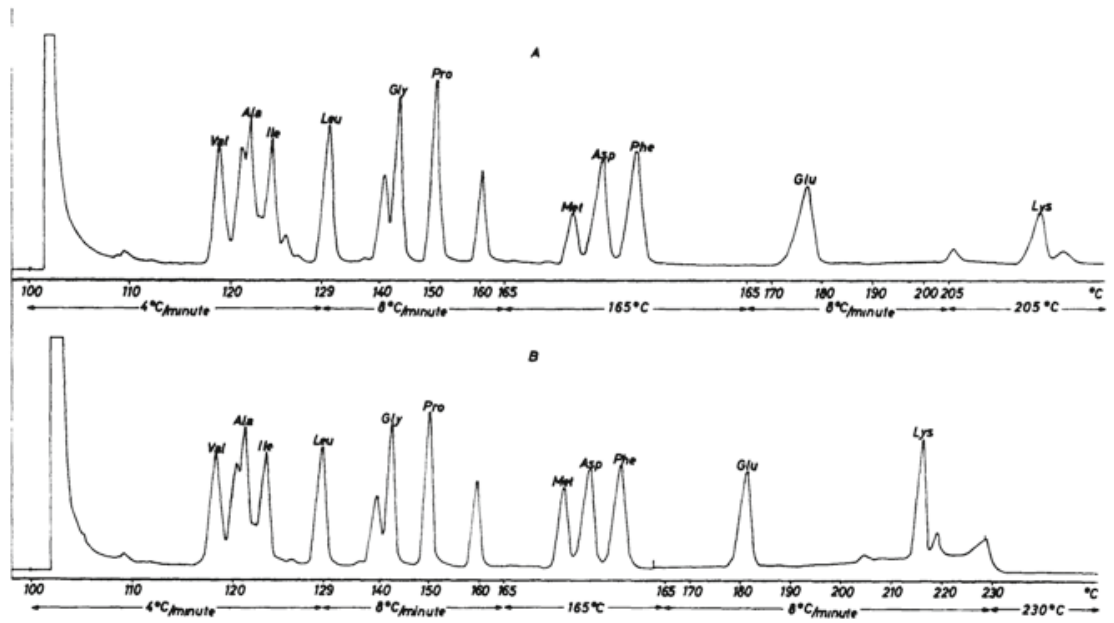

F i g u re 1. Gas chromatograms of N-TFA-amino acid n-butyl esters. Double column system with steel columns, $2 \mathrm{~m} \times 1 / 8^{\prime \prime}$, containing 1 per cent Carbowax 1500 on Chromosorb W, acid-washed, DMCS-treated, $80-100$ mesh. FID. Carrier gas $30 \mathrm{ml}$ helium per min. on each column. Injector temperature $350^{\circ} \mathrm{C}$.

A: No "hydrolysis". B: "Hydrolysis" (see text).

T a b le 1. Analysis of "non-hydrolysed" and "hydrolysed" amino acid mixture (see text). The result expressed in per cent of the area of the amino acids determined on the chromatograms in Fig. 1.

$\begin{array}{ccc}\text { Amino acid } & \text { No “hydrolysis" } & \text { "Hydrolysis" } \\ \text { Ala } & 8.7 & 8.7 \\ \text { Asp } & 10.7 & 10.2 \\ \text { Glu } & 9.6 & 8.8 \\ \text { Gly } & 10.1 & 9.3 \\ \text { Ile } & 8.5 & 8.2 \\ \text { Leu } & 10.2 & 9.9 \\ \text { Lys } & 5.3 & 7.4 \\ \text { Met } & 4.1 & 6.8 \\ \text { Phe } & 12.2 & 10.9 \\ \text { Pro } & 10.9 & 10.4 \\ \text { Val } & 9.6 & 9.5\end{array}$

hrs., a hydrochloric acid even as weak as $2.5 \mathrm{~N}$ produced complete hydrolysis.

A mixture of amino acids (the 11 determinable acids and the four hydroxy amino acids) was subjected to "hydrolysis" by the method indicated. Trifluoromethylation and esterification were now done on the "hydrolysed" portion and on an untreated por- 


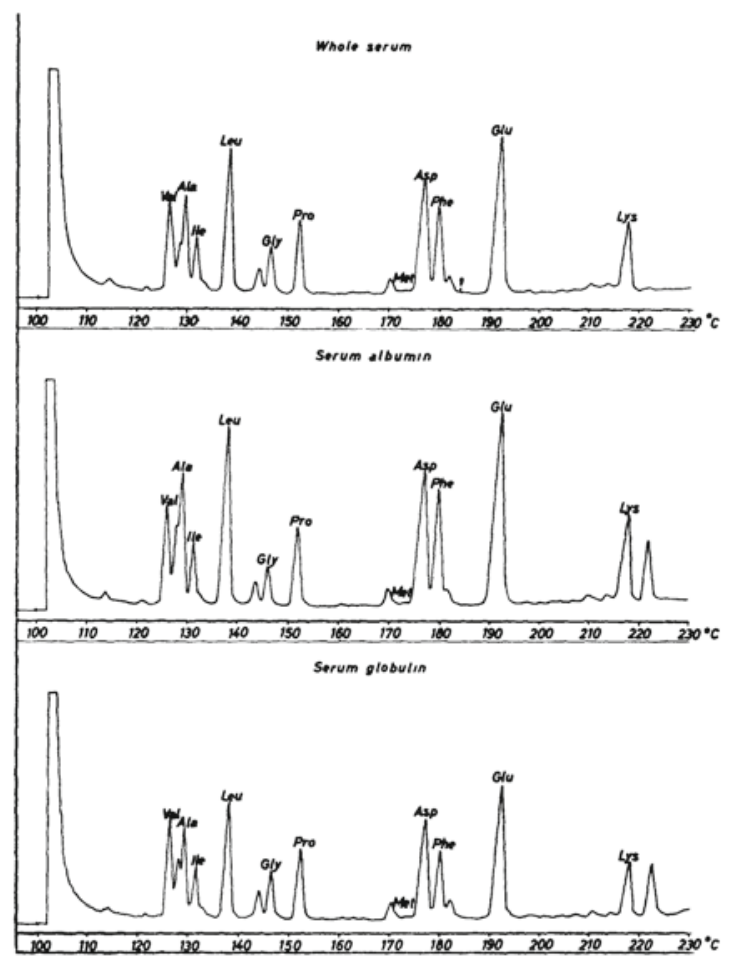

Fig u re 2. Gas chromatograms of protein hydrolysates. Concerning technique see Method.

T a b I e 2. Calculation of error of the method in 33 duplicate tests. *)

\begin{tabular}{lrrc} 
Acid & Mean value & Deviation & $\begin{array}{c}\text { Error of } \\
\text { the method }\end{array}$ \\
Ala & 7.1 & $5.6-8.1$ & 0.7 \\
Asp & 13.1 & $12.0-14.6$ & 0.4 \\
Glu & 19.0 & $16.8-22.3$ & 0.7 \\
Gly & 4.6 & $2.8-7.8$ & 0.4 \\
Ile & 4.5 & $3.5-5.5$ & 0.4 \\
Leu & 13.8 & $12.0-15.5$ & 0.5 \\
Lys & 14.2 & $7.3-21.9$ & 2.0 \\
Met ${ }^{\star *}$ ) & 0.6 & $0.2-1.0$ & 0.2 \\
Phe & 7.2 & $6.0-8.3$ & 0.4 \\
Pro & 6.9 & $5.6-8.2$ & 0.4 \\
Val & 9.2 & $6.7-11.7$ & 0.6 \\
\hline
\end{tabular}

*) Absolute error of the method $s=\sqrt{\frac{\Sigma \mathrm{d}^{2}}{2 \mathrm{n}}}$

**) Only 25 duplicate tests (see text). 
tion of the same amino acid mixture. The gas chromatograms are shown in Fig. 1 and the analyses in Table 1. As will be seen, no particular changes had taken place in the composition of the amino acids except as regards lysine and methionine, the percentage of which had apparently increased in relation to the total quantity of amino acids. This unaccountable phenomenon, which at all events does not indicate that any breakdown of amino acids takes place in the hydrolysis, necessitates "hydrolysis" also of the standards.

Fig. 2 shows three analyses of protein hydrolysate - a serum, the albumin alone, and the globulin alone in the same serum.

Table 2 shows the means of 33 duplicate tests made on each of 11 sera, 11 serum albumin samples and 11 serum globulin samples, all bovine. It also shows the absolute error of the method for the various analyses, calculated according to the formula $s=\sqrt{\frac{\Sigma d^{2}}{2 n}}$, where $s$ is the error of the method, $d$ is the difference between the two values in a duplicate test, and $n$ is the number of differences. This shows that especially lysine yields a rather uncertain result. The methionine content in the samples is fairly close to the limit of sensitivity of the method, and the table contains only the 25 duplicate tests in which both chromatograms showed methionine peaks big enough for planimetration. A better result would undoubtedly be obtained for all amino acids if the not particularly exact planimetering was replaced by evaluation with an integrator connected to the chromatograph.

In Table 3 the mean values of the 11 analyses of bovine serum albumin are compared with the results obtained by Stein \& Moore (1949) by column chromatography. The latter authors' values are here recalculated for comparison of the two series.

In its present form the method gives the results expressed as the percentage of each amino acid in relation to the total weight of amino acids identified in the sample. To obtain the absolute content of an amino acid in the sample, one can use two methods. One is the internal standard technique. A suitable internal standard would be $\gamma$-aminobutyric acid which yields a peak between proline and methionine on the chromatogram. Another way of obtaining quantitative results is to determine independently one or more of the acids in the sample. There are two conceivable 


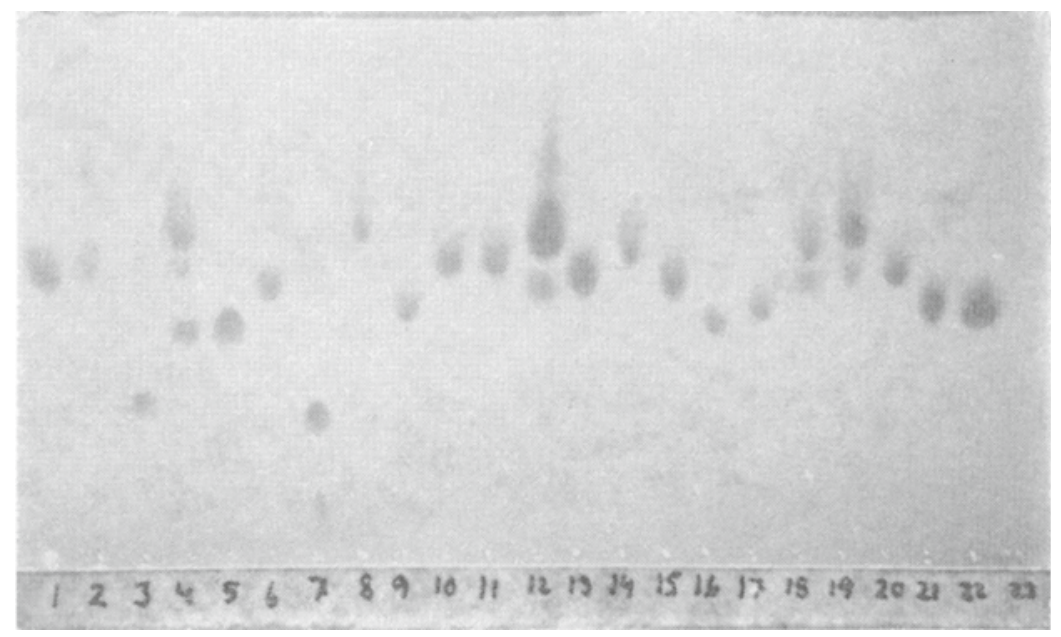

F i g u r e 3. Thin-layer chromatogram of DNP-amino acids. Phenolwater $(75: 25)$ on $0.25 \mathrm{~mm}$ Kieselgel G. Height $10 \mathrm{~cm}$. Time $90 \mathrm{~min}$. 1 Ala, 2 Arg, 3 Asp, 4 Cys, 5 Cys 6 Gly, 7 Glu, 8 His, 9 Hyp, 10 Ile, 11 Leu, 12 Lys, 13 Met, 14 Phe, 15 Pro, 16 Ser, 17 Thr, 18 Trp, 19 Tyr, 20 Val, 21 Citrulline, 22 Taurine.

T a b le 3. Amino acid analysis of bovine serum albumin. The content of each amino acid is expressed as its percentage of the total weight of amino acids determined.

\begin{tabular}{ccc} 
Acid & $\begin{array}{c}\text { Gas } \\
\text { chromatography }\end{array}$ & $\begin{array}{c}\text { Partition } \\
\text { chromatography **) }\end{array}$ \\
Ala & 7.0 & 7.7 \\
Asp & 13.0 & 13.4 \\
Glu & 20.2 & 20.3 \\
Gly & 3.2 & 2.2 \\
Ile & 4.0 & 3.2 \\
Leu & 14.7 & 15.1 \\
Lys & 16.6 & 15.8 \\
Met & 0.6 & 1.0 \\
Phe & 7.6 & 8.1 \\
Pro & 5.9 & 5.9 \\
Val & 7.5 & 7.3 \\
\hline
\end{tabular}

*) Mean of 11 (methionine 7) samples.

**) Stein \& Moore (recalculated, see text). 
means of doing this. One is determination of glycine by the method of Jewell et al. (1965). The other is determination of aspartic acid + glutamic acid by thin-layer chromatography of the DNP derivatives of the amino acids of the hydrolysate. These acids separate distinctly from all others when phenol-water (75:25) is used on Kieselgel G (Fig. 3). The two acids are eluated and the yellow colour of the solution is measured photometrically.

\section{REFERENCES}

Bayer, E., K.-H. Reuther \& F. Born: Analyse von Aminosäure-Gemischen mittels Gas-Verteilungschromatographie. Angew. Chem. 1957, 69, 640 .

Bier, M. \& P. Teitelbaum: Gas chromatography in amino acid analysis. Ann. N. Y. Acad. Sci. 1959, 72, 641-648.

Biserte, G., J. W. Holleman, J. Holleman-Dehove \& P. Sautière: Chromatographie sur papier des dinitrophénylaminoacides. J. Chromatog. 1959, 2, 225-271.

Blau, K. \& A. Darbre: Gas chromatography of volatile amino acid derivatives. II. Leucine, cysteine, proline, hydroxyproline, methionine, phenylalanine, aspartic acid and glutamic acid. J. Chromatog. 1965, 17, 445-449.

Blau, K. \& A. Darbre: Gas chromatography of volatile amino acid derivatives. III. Aspartic acid, lysine, ornithine, tryptophan and tyrosine. J. Chromatog. 1967, 26, 35-40.

Brenner, M., A. Niederwieser \& G. Pataki: Aminosäuren und Derivate. In E. Stahl: Dünnschicht-chromatographie. Ein Laboratoriumshandbuch. Springer-Verlag, Berlin, Göttingen, Heidelberg 1962, $403-445$.

Consden, R., A. H. Gordon \& A. J. P. Martin: Qualitative analysis of proteins: a partition chromatographic method using paper. Biochem. J. 1944, 38, 224-232.

Darbre, A. \& K. Blau: Gas chromatography of volatile amino acid derivatives. I. Alanine, glycine, valine, leucine, isoleucine, serine and threonine. J. Chromatog. 1965, 17, 31-49.

Darbre, A. \& $K$. Blau: Breakdown of trifluoroacetylated esters of cysteine and hydroxyl amino acids during gas chromatography: effects caused by some polar stationary phases. Biochim. biophys. Acta 1966, 126, 591-593.

Gehrke, C. W., W. M. Lamkin, D. L. Stalling \& F. Shahrokhi: Quantitative gas chromatography of amino acids. Biochem. biophys. Res. Comm. 1965, 19, 328-334.

Gehrke, C. W. \& F. Shahrokhi: Chromatographic separation of n-butyl $\mathrm{N}$-trifluoroacetyl esters of amino acids. Analyt. Biochem. 1966, 15, 97-108. 
Hagen, P. B. \& W. Black: Gas chromatographic method for the separation and estimation of amino acid derivatives. Canad. J. Biochem. 1965, 43, 309-315.

Ikekawa, N., O. Hoshino, R. Watanuki, H. Orimo, T. Fujita \& M. Yoshikawa: Gas chromatographic separation of DNP amino acids and its application to the analysis of serum amino acids. Analyt. Biochem. 1966, 17, 16-23.

Ishii, S.-I.\& B. Witkop: Gramicidin A. I. Determination of composition and amino acid configuration by enzymatic and gas chromatographic methods. J. Amer. chem. Soc. 1963, 85, $1832-1834$.

Ishii, S.-I. \& B. Witkop: Gramicidin A. II. Preparation and properties of "seco-Gramicidin A". J. Amer. chem. Soc. 1964, 86, 18481853.

IUPAC-IUB Commission on Biochemical Nomenclature: Abbreviated designation of amino acid derivatives and peptides. Tentative rules. J. biol. Chem. 1966, 241, 2491-2495.

Jewell, J. P., M. J. Morris \& R. L. Sublett: Colorimetric quantitative method for determining glycine in presence of other amino acids. Analyt. Chem. 1965, 37, 1034-1035.

Johnson, D. E., S. J. Scott \& A. Meister: Gas-liquid chromatography of amino acid derivatives. Analyt. Chem. 1961, 33, 669-673.

Kanomata, K. \& Y. Mashiko: Pyrolysis gas chromatography of amino acids and proteins. Nippon Kagaku Zasshi 1966, 87, 57-62.

Katz, S. \& A. Lewis: Apparatus for high-voltage thin-layer electrophoresis: application to amino acid analysis. Analyt. Biochem. 1966, 17, 300-309.

Lamkin, W. M. \& C. W. Gehrke: Quantitative gas chromatography of amino acids. Preparation of n-butyl N-trifluoroacetyl esters. Analyt. Chem. 1965, 37, 383--389.

Liberti, A.: Discussion in D. H. Desty: Gas Chromatography 1958, $341-342$.

Losse, G., A. Losse \& J. Stöck: Gaschromatographische Trennung von N-Formyl-aminosäure-methylestern. Z. Naturforsch. 1962, 17, $785-786$.

Martin, A. J. P.\& R. L. M. Synge: Separation of the higher monoaminoacids by counter-current liquid-liquid extraction: the aminoacid composition of wool. Biochem. J. 1941a, 35, 91-121.

Martin, A.J.P.\& R. L.M. Synge: A new form of chromatogram employing two liquid phases. 1. A theory of chromatography. 2. Application to the micro-determination of the higher monoaminoacids in proteins. Biochem. J. 1941b, 35, 1358-1368.

Moore, S. \& W. H. Stein: Chromatography of amino acids on starch columns. Solvent mixtures for the fractionation of protein hydrolysates. J. biol. Chem. 1949, 178, 53-77.

Moore, S. \& W.H.Stein: Chromatography of amino acids on sulfonated polystyrene resins. J. biol. Chem. 1951, 192, 663-681. 
Moore, S. \& W. H. Stein: Procedures for the chromatographic determination of amino acids on four per cent cross-linked sulfonated polystyrene resins. J. biol. Chem. 1954a, 211, 893-906.

Moore, S. \& W. H. Stein: A modified ninhydrin reagent for the photometric determination of amino acids and related compounds. J. biol. Chem. 1954b, 211, 907-913.

Rühlmann, K. \& G. Michael: Analyse par chromatographie en phase gazeuse de dérivés silyliques des acides aminés. Sur la liaison Si-N-XVII. (1). Bull. Soc. Chim. biol. (Paris) 1965, 47, 14671475 .

Saroff, H. A. \& A. Karmen: Gas chromatography of the N-trifluoroacetylmethyl esters of the amino acids. Analyt. Biochem. 1960, 1, $344-350$.

Stack, M. V.: Pyrolysis and gas chromatography of amino acids and proteins. Biochem. J. 1965, 96, $56 \mathrm{P}$.

Stein, W. H. \& S. Moore: Amino acid composition of $\beta$-lactoglobulin and bovine serum albumin. J. biol. Chem. 1949, 178, 79-91.

Wagner, J. \& G. Rausch: Gas-chromatographische Trennung und Bestimmung von Aminosäuren. II. Gas-chromatographische Trennung und Bestimmung von Aminosäuren in Form der Hydroxysäuremethylester. Z. analyt. Chem. 1963, 194, 350-356.

Wagner, J. \& G. Winkler: Die gaschromatographische Trennung und Bestimmung von Aminosäuren. Die gaschromatographische Bestimmung von Aminosäuren in Form ihrer N-Trifluoracetylmethylester. Z. analyt. Chem. 1961, 183, 1-11.

Wang, K.-T., J. M. K. Huang \& I. S. Y. Wang: Polyamide layer chromatography of DNP-amino acids. J. Chromatog. 1966, 22, 362-368.

Winter, L. N. \& P. W. Albro: Differentiation of amino acids by gasliquid chromatography of their pyrolysis products. J. Gas Chromatog. 1964, 2, 1-6.

Virtanen, A. I. \& N. Rautanen: On the micro method for estimation of amino acids based on formation of volatile aldehydes by ninhydrine oxidation. Suom. Kemisti-L. 1945-46, 18-19, 56-59.

Virtanen, A. I. \& N. Rautanen: Determination of certain aminoacids by ninhydrine oxidation to volatile aldehydes. Biochem. J. 1947, $41,101-105$.

Youngs, C. G.: Analysis of mixtures of amino acids by gas phase chromatography. Analyt. Chem. 1959, 31, 1019-1021.

Zlatkis, A., J. F. Oró \& A. P. Kimball: Direct amino acid analysis by gas chromatography. Analyt. Chem. 1960, 32, 162-164.

Zomzely, C., G. Marco \& E. Emery: Gas chromatography of the n-butyl$\mathrm{N}$-trifluoroacetyl derivatives of amino acids. Analyt. Chem. 1962, $34,1414-1417$. 


\section{SUMMARY}

A gas chromatographic method is described by which 11 amino acids in protein hydrolysate can be determined. They are: alanine, aspartic acid, glutamic acid, glycine, isoleucine, leucine, lysine, methionine, phenylalanine, proline and valine. The result is presented as the percentage of the amino acid in relation to the total weight of amino acids determined. Means of making the method quantitative are indicated.

\section{ZUSAMMENFASSUNG}

Eine Methode für gaschromatographische Bestimmung von 11 Aminosäuren in Protein-Hydrolysaten.

Eine gaschromatographische Methode ist beschrieben, womit man 11 Aminosäuren in Protein-Hydrolysaten bestimmen kann. Die Aminosäuren sind: Alanin, Asparaginsäure, Glutaminsäure, Glykokoll, Isoleucin, Leucin, Lysin, Methionin, Phenylalanin, Prolin und Valin. Das Resultat liegt als die prozentuelle Anteil des Aminosäures vom totalen Gewicht der bestimmten Aminosäuren im Probe for. Verfahren, die Methode quantitativ zu machen, sind vorgeschlagen.

\section{SAMMANFATTNING}

En metod för gaskromatografisk bestämning av 11 aminosyror $i$ proteinhydrolysat.

En gaskromatografisk metod beskrives, varigenom 11 aminosyror i proteinhydrolysat kan bestämmas. De 11 aminosyrorna är: alanin, asparaginsyra, glutaminsyra, glykokoll, isoleucin, leucin, lysin, methionin, phenylalanin, prolin och valin. Resultatet angives såsom aminosyrans procentuella andel $\mathrm{i}$ den totala vikten bestämda aminosyror $\mathrm{i}$ provet. Möjligheter att göra metoden kvantitativ anges.

(Received December 14, 1967). 